\title{
Il disegno narrato. Esplicitare algoritmi per insegnare la modellazione digitale
}

\author{
Michele Calvano \\ Massimiliano Lo Turco \\ Elisabetta Caterina Giovannini \\ Andrea Tomalini
}

Abstract

Gli strumenti per il disegno dell'architettura si sono rapidamente evoluti negli ultimi anni, integrando il disegno manuale con l'uso dell'elaboratore: attraverso strumenti sempre più evoluti le più recenti piattaforme digitali, se sapientemente utilizzate, consentono un profondo e trasversale controllo del processo progettuale e costruttivo, favorendo la gestione di livelli di complessità che il disegno tecnico non permette di perseguire. Pur senza rinunciare alla capacità espressiva e ideativa del disegno manuale, i nuovi strumenti lavorano in modo efficiente sulle relazioni che intercorrono tra logica e forma, tra geometria e attributi.

E cambiato il paradigma del disegno, un cambiamento già in atto nella pratica professionale, che va integrato all'interno dell'accademia; solo in questo modo le procedure digitali verranno pienamente dominare dai futuri progettisti per ottenere progetti dalla forma 'etica'.

II presente contributo si propone di ragionare criticamente su queste istanze, tra teorica e tecnica, accompagnando la narrazione con alcune interessanti e originali esperienze didattiche che si propongono di esplorare l'integrazione tra saperi diversi, indagando possibili connessioni tra un rigoroso approccio geometrico/logico/formale proprio dei sistemi di programmazione visuale (VPL - Visual Programming Language) utilizzando la rappresentazione esplicita.

Parole chiave

scienze della rappresentazione, didattica, integrazione di saperi, geometria descrittiva, disegno esplicito

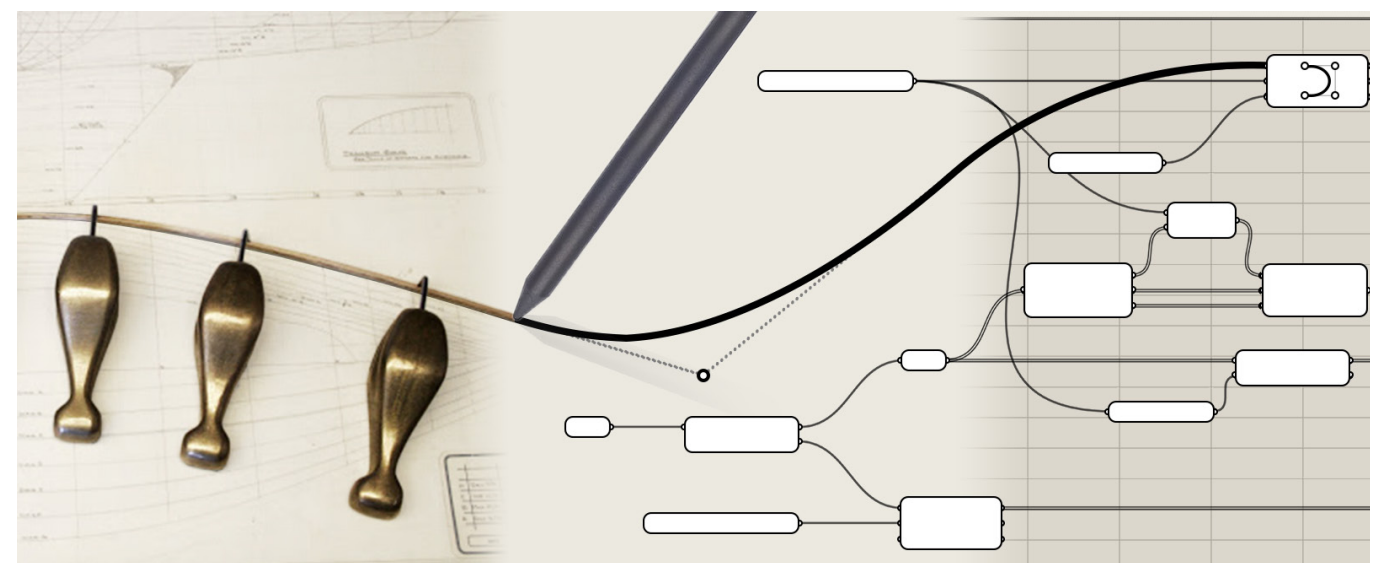




\section{Dal disegno digitale al Disegno Digitale Esplicito}

Da diversi anni il settore del Disegno si avvale di diversi strumenti digitali, indagando connessioni tra i metodi classici del disegno e i metodi digitali. Ricordiamo che per metodi classici intendiamo le proiezioni ortogonali, l'assonometria e la prospettiva, per metodi digitali intendiamo la rappresentazione matematica (NURBS) e la rappresentazione numerica (mesh). I metodi digitali sono stati ampiamente dibattuti nel tempo nell'area del Disegno [Baglioni 20 I2; Bartoli et al. 20 I6], producendo un'ampia letteratura, arricchita di sperimentazioni che illustrano limiti e potenzialità dei metodi digitali.

Ancora in atto è la discussione sul ruolo dei metodi classici di rappresentazione nell'era del disegno digitale in cui gli strumenti adottati supportano diversi ambiti del progetto d'architettura. L'apprendimento della modellazione 3D oggi passa per il Building Information Modeling, in cui le possibilità della simulazione in questi ambienti affronta contemporaneamente l'organizzazione spaziale e costruttiva, funzionale e formale, quantitativa ed economica e le potenzialità prefigurative del progetto costruito superano le possibilità speculative sulla forma consentite da un software CAD. II primo, decisamente votato alla gestione di progetto e di processo, riesce a restituire rappresentazioni tecniche che vanno dalla scala architettonica fino alla scala esecutiva dell'opera; il secondo è invece in grado di completare la prima parte del processo progettuale che riguarda la gestione della forma in ambito concettuale (figg. I, 2).

Fig. I. Prospetto e sezione del progetto definitivo redatti con l'ausilio di software BIM. Scala originale 1:200 (studenti: E. Melano, A. Pizzo, L. Stojan).

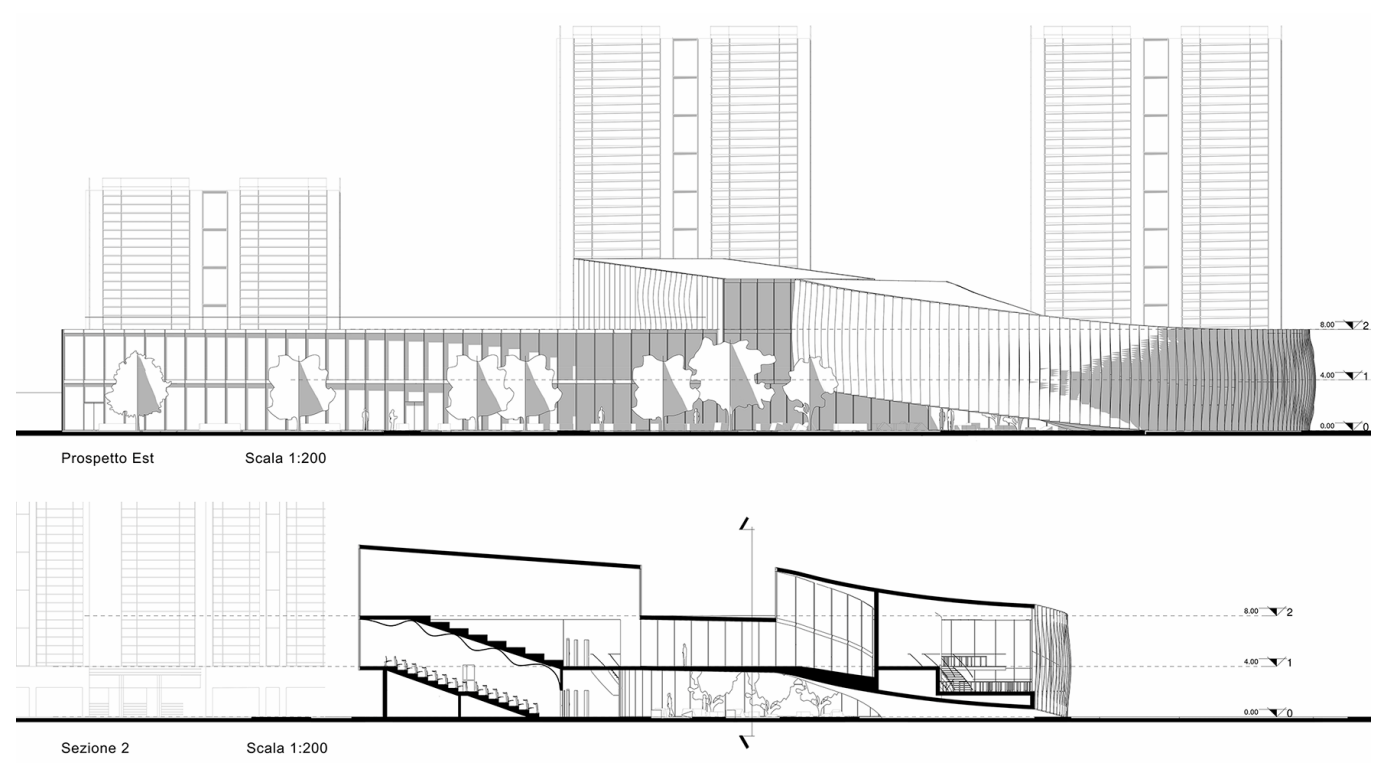

Considerate le peculiarità complementari tra i due strumenti, sarebbe interessante creare un dialogo tra i due ambienti; la creazione di un unico percorso necessita di strategie per dare continuità alla naturale consequenzialità dei modelli: parliamo di immagini diverse dell'idea progettuale che matura durante il percorso ideativo permettendo al disegno un passaggio di scala. La necessità è quella di costruire ponti, connettere i metodi, rendere i modelli interoperabili.

Ultimamente i software di disegno si stanno dotando di interfacce grafiche per la programmazione visuale con cui manipolare le forme che lo stesso software mette a disposizione, attraverso il Visual Programming Language. L'avvento di questi applicativi integrati nei software, concede diversi gradi di libertà al disegnatore. Ci si rende conto, infatti, che le interfacce dei programmi collezionano in maniera tematica le componenti di costruzione e modifica delle forme, raggruppando in appositi menù i comandi di gestione dei documenti creati. La User Interface (UI) è sicuramente un valido supporto all'immediato utilizzo dei programmi di disegno, rendendo familiari strumenti che in realtà sono utilizzati per la generazione di 
Fig. 2. Schematizzazione della forma architettonica concettuale in ambiente CAD tramite la costruzione di un modello continuo (studenti: E. Melano, A. Pizzo, L. Stojan)

Fig. 3. UI di alcuni degli applicativi VPL più utilizzati: Dynamo e Marionette (a sinistra); Grasshopper e Sverchok (a destra); $<$ primer.dynamobim.org/, forum.vectorworks.net/, archiradarit/, nikitron. cc.ua/>

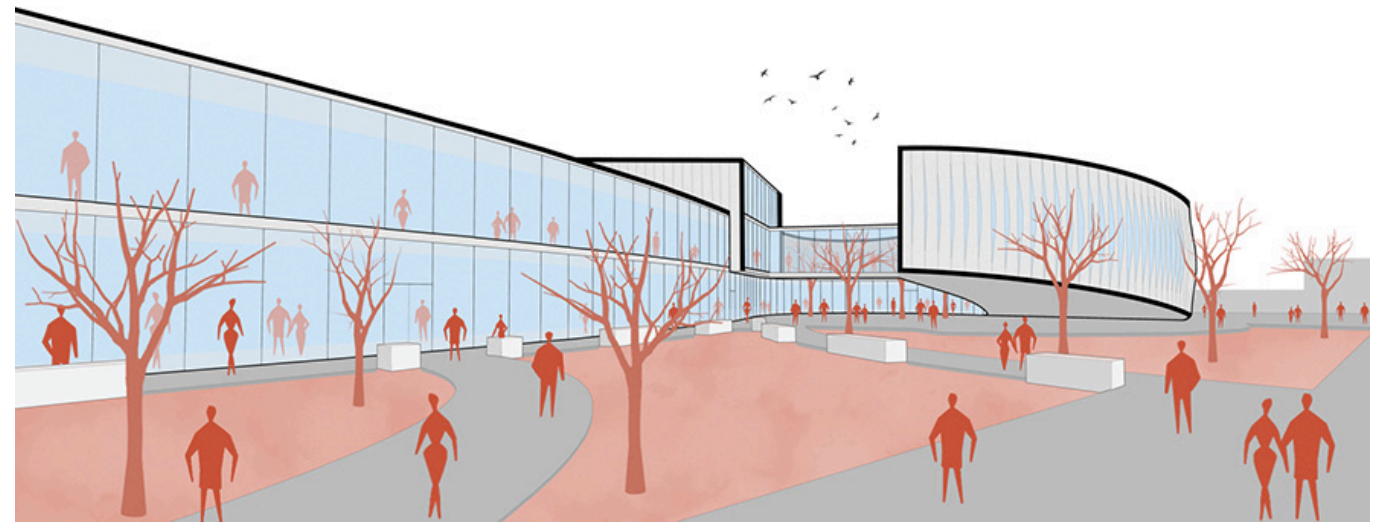

modelli; le stesse UI però risultano essere un velo che cela, attraverso l'utilizzo di macro, le potenzialità intrinseche dello strumento: questo è forse una delle ragioni per cui l'apporto digitale nell'ambito del disegno non ha ancora espresso le sue piene potenzialità capaci di rivoluzionare la concezione della forma e la comprensione dello spazio.

Le interfacce rendono i software dei grandi tavoli da disegno in cui le barre che collezionano i comandi, non sono altro che cassetti contenenti un numero limitato di strumenti assimilabili a quelli posseduti dagli ormai antichi e desueti tecnigrafi: i diversi comandi per la costruzione di forme sono piccoli percorsi precostituiti che, attraverso l'introduzione di parametri restituiscono oggetti semplici; dall'insieme di questi oggetti e dalla loro interconnessione si prefigurano le forme. II paradigma compositivo non è particolarmente mutato nel tempo, se non in alcuni aspetti che riguardano la maggiore rapidità di comunicazione degli step compositivi e della produzione di elaborati tecnici.

Se nell'approccio originale al modello la costruzione è fondata sulla composizione di macro precostituite, l'approccio grafico-computazionale consente di entrare nell'essenza informatica delle entità che si generano in ambiente digitale. La parola modello diventa chiave in questo modo di ragionare; un modello informatico di un edificio è in potenza non solo una costruzione tridimensionale che permette infiniti punti di vista, ma anche un modello scientifico: modello matematico, finanziario fisico, statistico. I dati sono interrelati e al mutare di uno variano anche gli altri [Saggio 2007].

Gli aspetti computazionali esigono la conoscenza dei linguaggi di programmazione per manipolare in maniera diretta le librerie che codificano le entità grafiche; la conoscenza di lin-
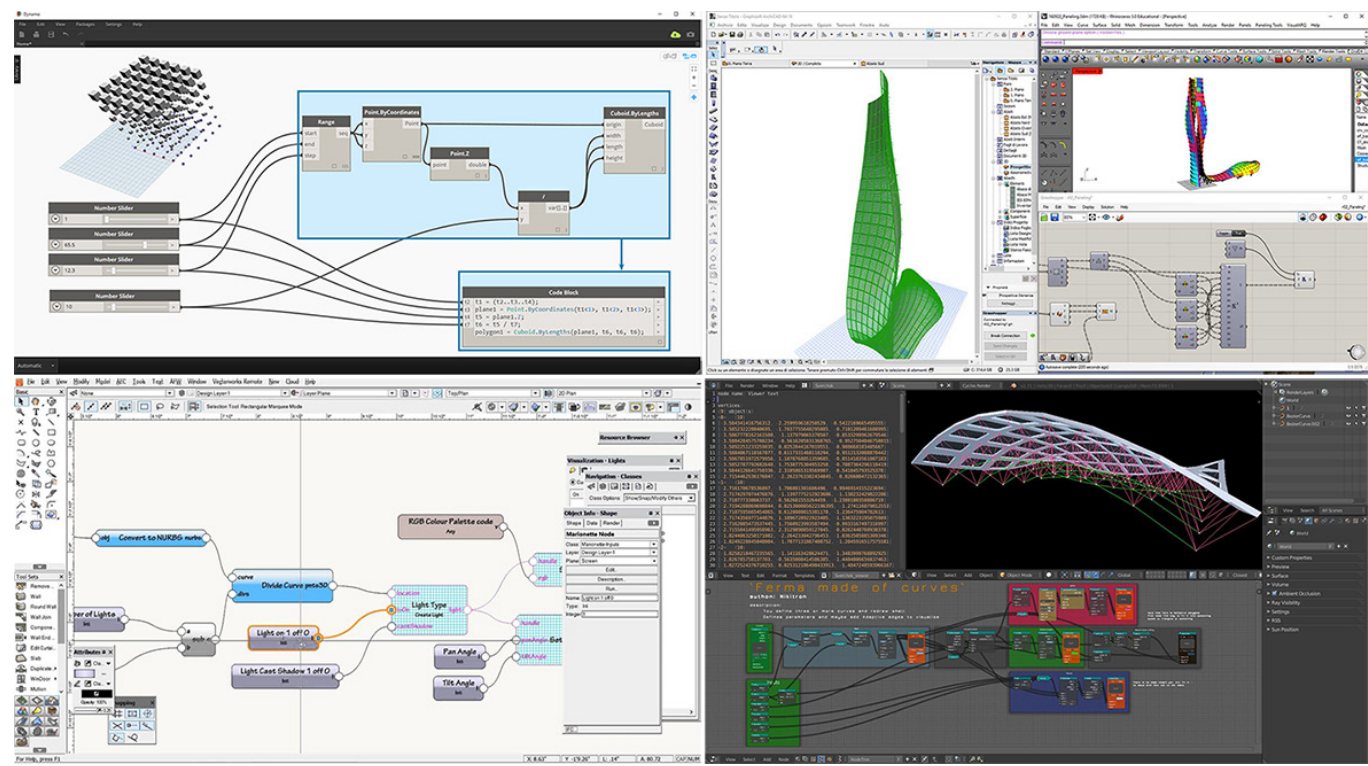
Fig. 4. Sergio Musumeci, modello per determinare la forma del Ponte sul Bafebbraio 1977, p. 77-98)

Fig. 5. Frame del video The Institute for Lightweight Structure (IL) University of Stuttoart Direttore: Fre Otto. guaggi legati alla composizione di istruzioni minime, diventa spunto di una evoluta creatività progettuale: una sapiente gestione del livello informativo delle entità geometriche consente di aggiungere "ingredienti nuovi" al disegno per generare forme evolute (fig. 3). Nel tempo, progettisti pionieri hanno introdotto regole diverse da quelle imposte dalla riga e dalla squadra, ibridando informazioni provenienti da altri settori (Antoni Gaudì, Otto Frei, Felix Candela, Sergio Musmeci): la fisica meccanica, la matematica, la statica. La forma è quindi svincolata dalle regole tradizionali di composizione dell'architettura. II Disegno Digitale Esplicito (DDE), attraverso il principale strumento del Visual Programming Language, rende democratico il processo di ibridazione (figg. 4, 5).

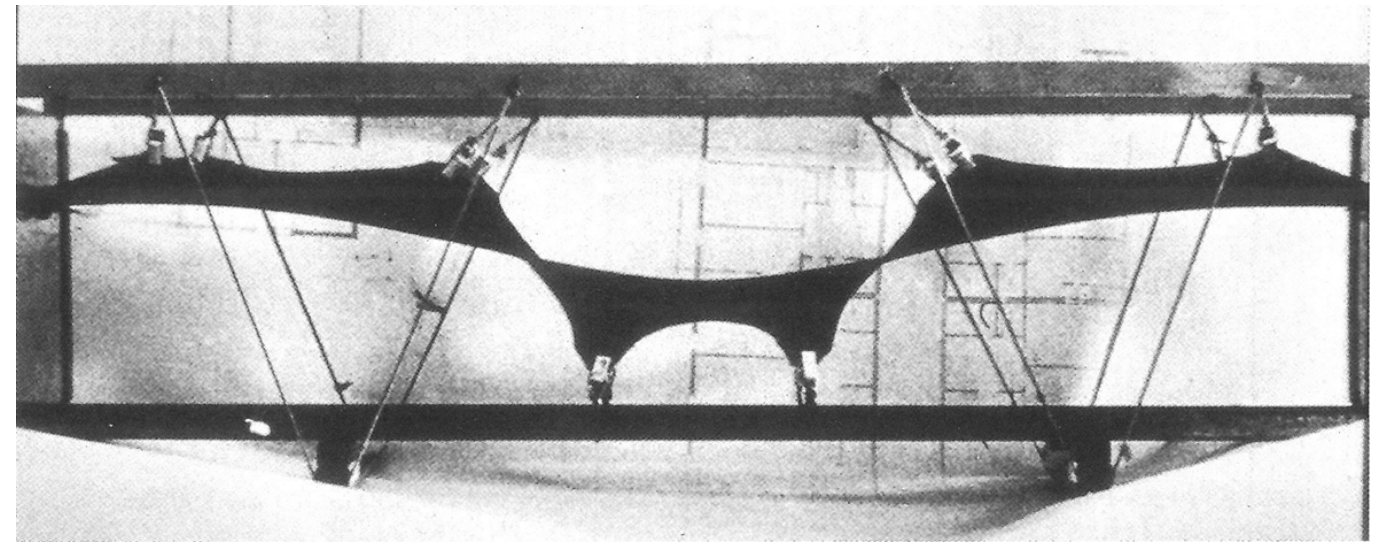

Con Disegno Digitale Esplicito (DDE) intendiamo quella modalità di rappresentazione dei modelli ove l'attenzione del disegnatore è rivolta non solo al risultato formale, ma anche alle procedure che hanno generato l'immagine. L'equilibrio tra procedura e prodotto mette in evidenza nuove modalità creative che si manifestano tanto nel prodotto visuale, quanto nelle procedure che generano il modello. La capacità di costruire relazioni efficienti tra dati e informazioni collegate a un modello visuale, è uno degli scopi del DDE [Calvano 2019]. Queste poche righe descrivono sinteticamente il ruolo del disegnatore che decide di avvalersi delle nuove tecniche informatiche per la rappresentazione dei modelli, attraverso una modalità di disegno controllata che utilizza strumenti di codifica visuale capaci di indagare nuovi ambiti della rappresentazione. Ambiti di cui le discipline del disegno devono impadronirsi, innescando un processo di revisione degli insegnamenti nei corsi di disegno delle scuole d'architettura. Da dove iniziare? Probabilmente dalle basi.

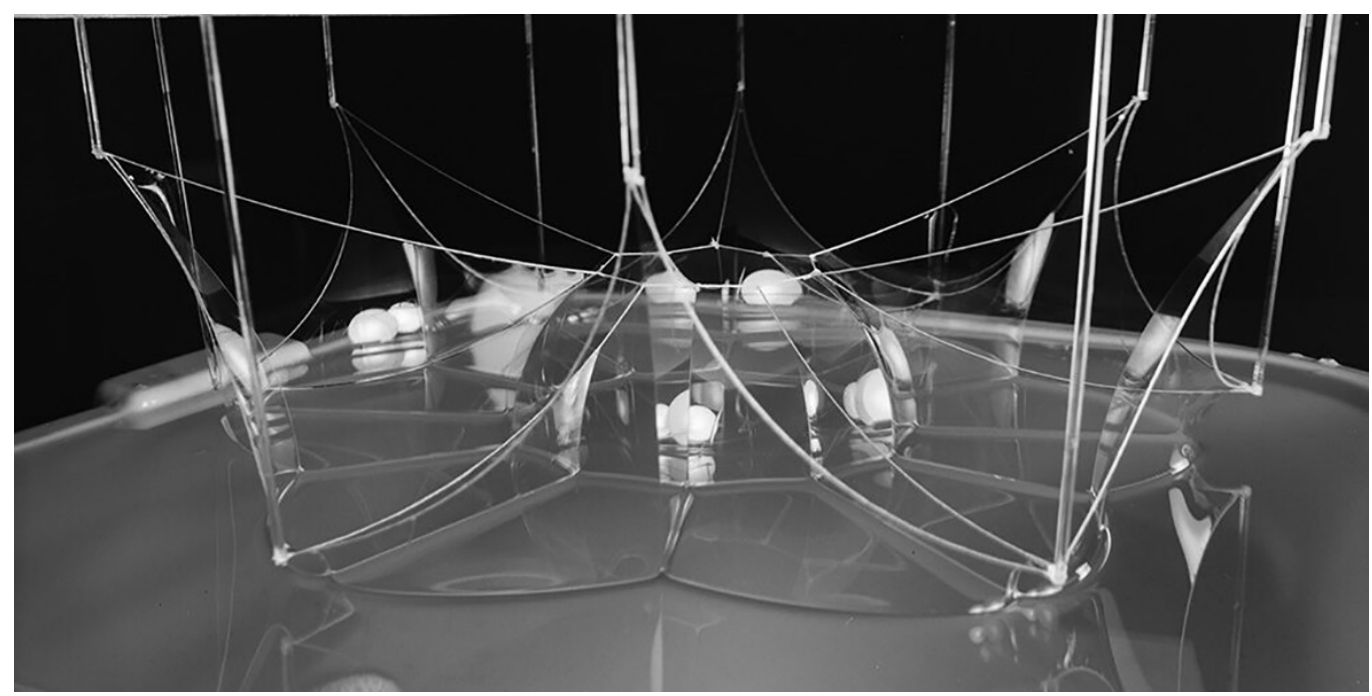




\section{Gli enti geometrici fondamentali - decostruzione}

II Disegno Digitale Esplicito è un approccio basato sui nuovi metodi di rappresentazione, pur riconducendo le sue basi fondative ai metodi classici, poiché con essi è possibile addestrare la mente all'uso degli algoritmi generativi della forma.

Nel volume Geometria Creativa [Casale 20 I 0], l'autore introduce nelle prime pagine gli enti geometrici fondamentali, disegnando sul foglio di carta un cubo in assonometria per poi smontarlo negli elementi che lo costituiscono: facce, linee e punti, definendoli "Elementi semplici, idee o concetti primitivi, necessari alla visione e alla conoscenza prima ancora che alla rappresentazione" [Casale 2010, p. 17]. La dissertazione prosegue, giungendo alla definizione della retta: "il piano frontale del cubo interseca la faccia superiore, definendo una porzione di retta. La retta può essere espressa solo attraverso la sua lunghezza, è monodimensionale. II cubo è definito da 12 porzioni di rette, i suoi spigoli”' [Casale 20 I0, p. I7]. . L'elemento semplice per la comprensione degli enti geometrici fondamentali è il cubo, che nel campo bidimensionale del foglio di carta è rappresentato da un'immagine evocativa costituita da unaserie di segni che richiamano l'oggetto reale pieno. II metodo della rappresentazione matematica propone come entità semplice la bRep (boundary Representation), che rappresenta le entità principali attraverso i suoi confini. Il disegno esplicito permette di recuperare le nozioni precedentemente enunciate per esprimere le nuove entità minime. II parallelepipedo in figura 6. è una bRep che viene ridotta alle sue entità minime attraverso un processo di decostruzione dell'oggetto. Per esprimere questa semplice procedura utilizziamo Grasshopper, uno dei VPL più utilizzati in ambito di ricerca. In figura è riportata la componente Deconstruct Brep; in input (Brep) si chiede l'introduzione di un solido aperto o chiuso per poi decostruirlo nelle liste delle entità minime che lo costituiscono: facce (faces), spigoli (edges), vertici (vertices). Inserendo un pannello di lettura per ogni output elencato, si visualizza una vera e propria lista dove le entità sono indicizzate con una sequenza numerica che parte da 0 e arriva a $n$, dove $n$ è determinato dal numero degli elementi specifici che costruiscono la forma; per un cubo avremo 6 facce, 12 spigoli e 8 vertici. Notiamo

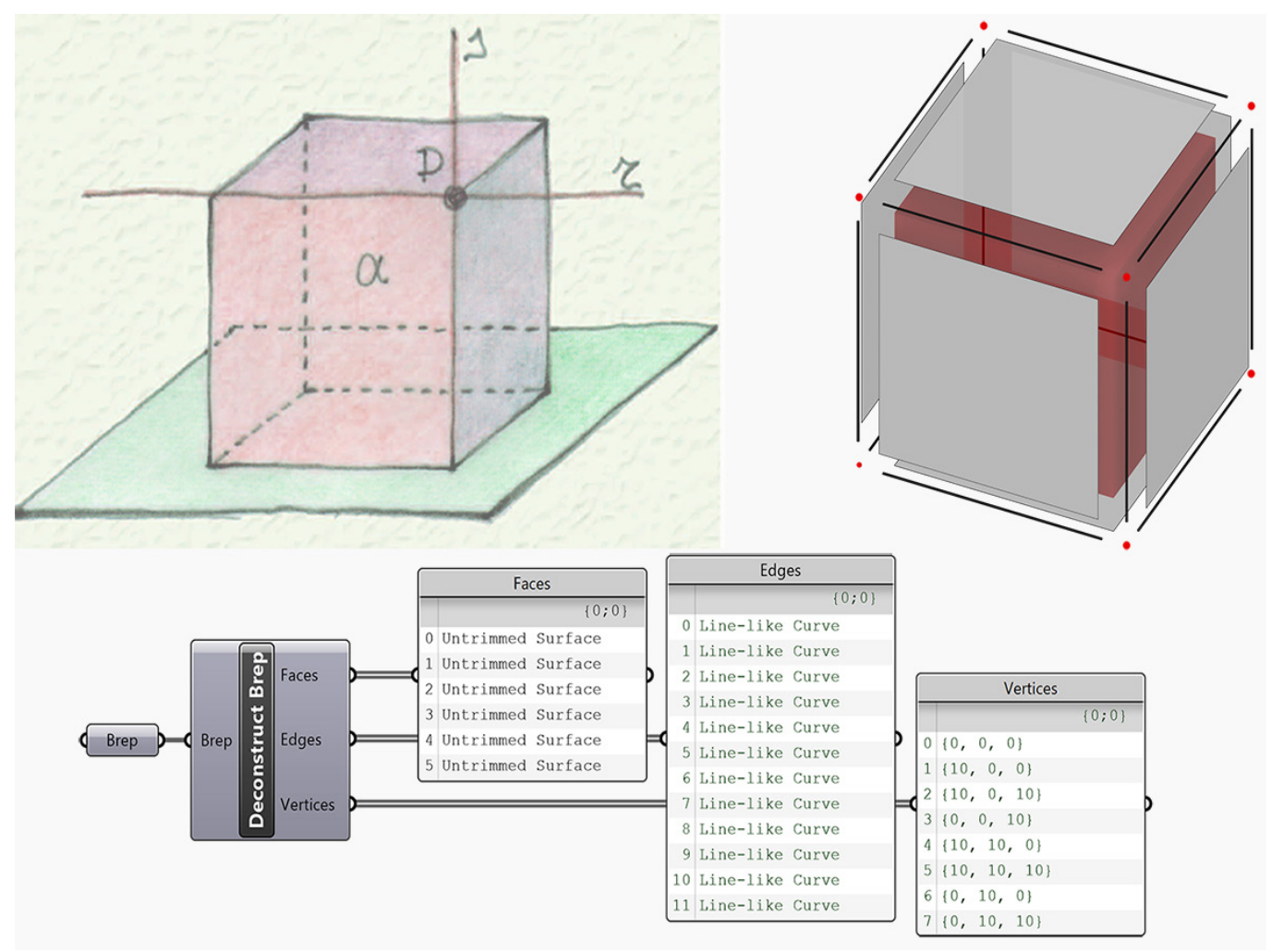


come il disegno esplicito sia una modalità di costruzione/decostruzione della forma la cui comprensione trova giovamento 'nell'addestramento algoritmico' alla geometria descrittiva.

\section{Le condizioni di appartenenza - topologia}

La geometria descrittiva, attraverso i metodi classici di rappresentazione è in grado di descrivere sul piano le scene presenti nello spazio. La trasposizione degli eventi dal dominio tridimensionale al dominio bidimensionale è possibile partendo da chiare regole legate alle condizioni di appartenenza:

- Due punti distinti individuano una retta alla quale appartengono e che gli appartiene.

- Due piani distinti individuano una retta che gli appartiene, alla quale appartengono.

- Due rette che s'intersecano in un punto, individuano un piano che gli appartiene, al quale appartengono.

- Due rette parallele individuano un piano che gli appartiene, al quale appartengono.

- Tre punti che non appartengono alla medesima retta, individuano un piano che gli appartiene, al quale appartengono.

- Tre piani che non appartengono alla medesima retta, individuano un punto che gli appartiene, al quale appartengono.

- Un piano e una retta, che non si appartengono, individuano un punto che gli appartiene, al quale appartengono.

- Un punto e una retta che non si appartengono, individuano un piano che gli appartiene, a cui appartengono.

I metodi di rappresentazione digitale definiscono le condizioni di appartenenza mediante le condizioni topologiche, la conoscenza delle prime agevola la comprensione delle seconde. Usiamo ancora il linguaggio di programmazione visuale per capire in quale modo le condizioni di appartenenza, nella modellazione 3D, si convertono in relazioni topologiche tra le parti che costituiscono il modello. Un altro modo per definire i solidi in ambiente digitale è la polisuperficie: nel software si traduce in una collezione di entità (punti, linee e superfici)

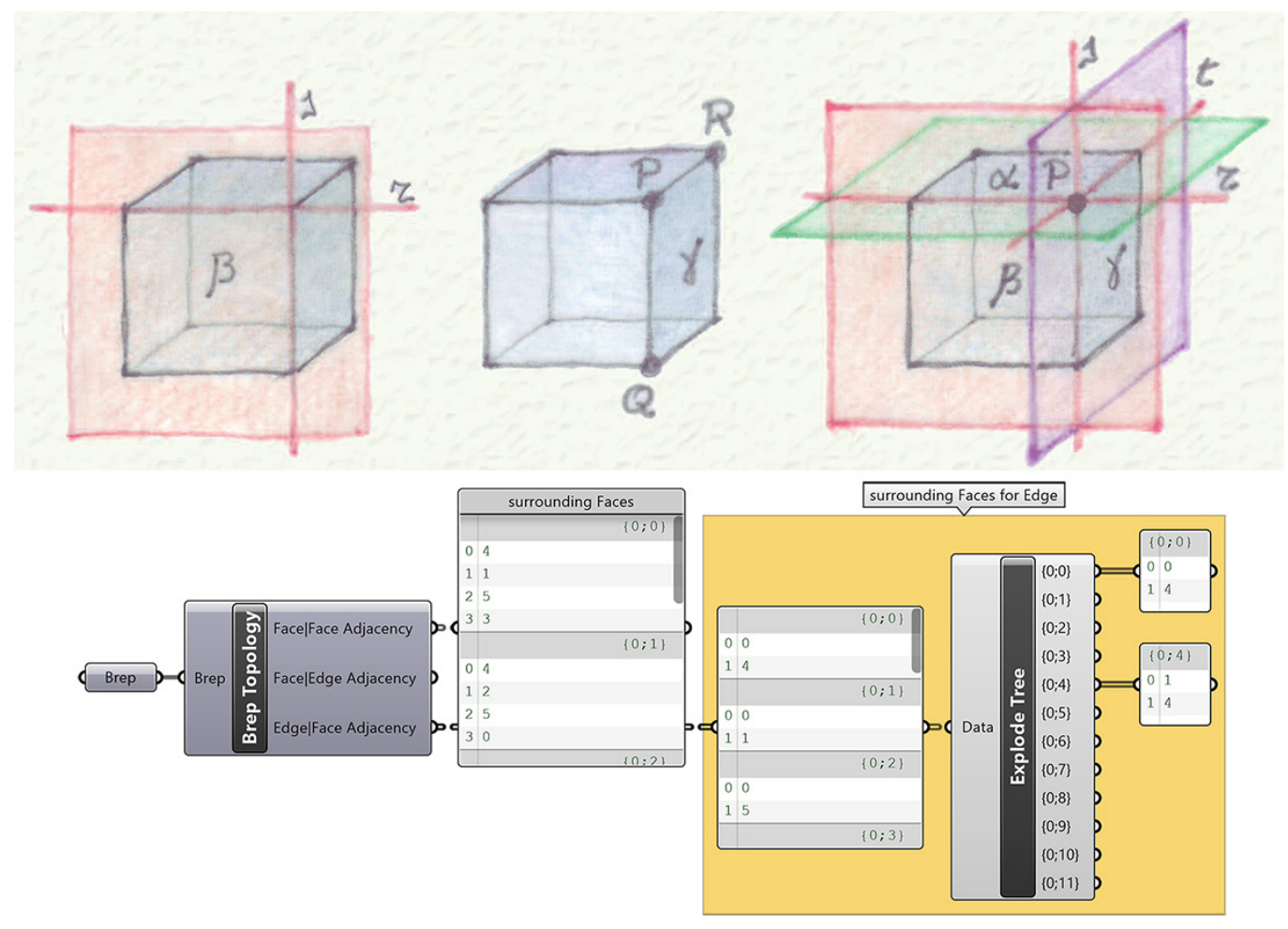


legate tra loro da relazioni di appartenenza; queste determinano un collante che conferisce integrità al poliedro rappresentato, ovvero la topologia definita da una nuova lista di relazioni che, insieme alla lista delle entità minime costituenti il solido, ne determina l'identità all'interno della scena digitale.

Per comprendere meglio il concetto si introduce la componente Brep Topology (fig. 7): una volta acquisita la polisuperficie, la componente elenca per ogni faccia le rispettive facce adiacenti (Face - Face Adjacency) e gli spigoli adiacenti (Face - Edge Adjacency); e ancora, per ogni spigolo estrae un elenco di facce che vi convergono (Edge - Face Adjacency).

Se si utilizza un pannello e lo si collega alla prima uscita della componente in esame si può comprendere come viene numericamente indicata la topologia: la lista che generalmente è visualizzata con un elenco continuo di dati si spezza, creando dei raggruppamenti individuati da indici numerici inclusi tra parentesi graffe (fig. 7). Nel caso specifico il primo numero interno alle parentesi graffe è sempre 0 . Separato da un punto e virgola vi è un ulteriore numero che identifica la faccia di riferimento. Gli elementi appartenenti a ogni raggruppamento rappresentano gli indici delle facce adiacenti a quella definita dal raggruppamento. Le rappresentazioni esplicite descritte in dettaglio evidenziano come gli algoritmi visuali prodotti conducano a un nuovo grado di complessità. Esplicitare un codice nel tempo determina la costruzione di una struttura gerarchica, che trasporta il dato e lo trasforma, creando delle dipendenze parallele; si vengono dunque a creare nuove condizioni di appartenenza non più apprezzabili visivamente ma che richiedono una capacità di astrazione non più legata all'ambito disciplinare del disegno (fig. 8).

Questo è il punto in cui la rappresentazione traguarda i suoi confini per affacciarsi a un mondo informatico da cui trarre quella linfa utile ad alimentare l'evoluzione della disciplina.

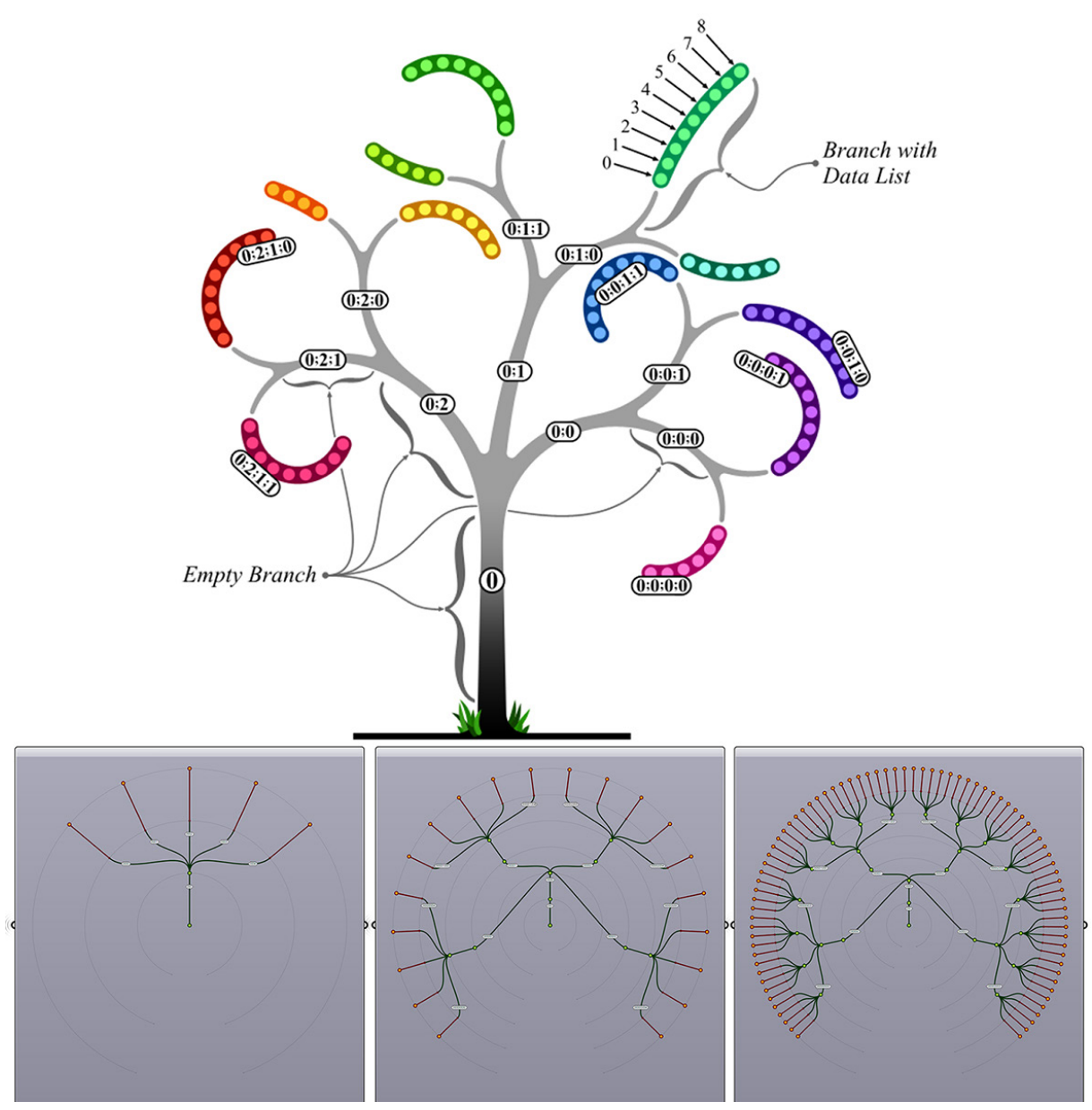




\section{Consistenza e prefigurazione del DDE}

II disegno esplicito, nel determinarsi attraverso il VPL lascia traccia di sé, interrompendosi una volta raggiunta l'immagine finale della forma perseguita. La traccia può essere modificata in maniera non lineare, si può ramificare e semplificare nell'ottica di un'efficienza computazionale. Un nuovo linguaggio che può essere scritto e letto, assumendo una ulteriore logica narrativa. Quest'ultima proprietà le conferisce un indubbio valore didattico; identici obiettivi possono essere raggiunti mediante approcci diversi, che si manifestano lasciando tracce grafiche delle diverse sperimentazioni (fig. 9).

La logica narrativa della scelta è l'autentica innovazione nell'ambito del disegno informatico poiché costituisce l'essenza dell'innovazione digitale: la possibilità di elaborare flussi di informazioni, anche di natura eterogenea, utili a sviluppare nuovi concetti formali [Valenti, Romor 2012].

È una modalità aperta e interoperabile, capace di creare un ponte tra le discipline. Si moltiplicano i corsi universitari in diverse sedi italiane che utilizzano il disegno esplicito per il dialogo tra le discipline all'interno di atelier e corsi multidisciplinari, ne riportiamo solo alcuni. L'insegnamento di Product Design Studio, all'interno del corso di Laurea Magistrale in Product Design del primo anno alla Sapienza di Roma. Mediante il disegno esplicito gli studenti gestiscono in un workflow unico continuamente modificabile, le operazioni di reverse modeling su point cloud, le operazioni di modellazione della forma e la fabbricazione digitale.

Più legato alle forme responsive è il Laboratorio di Modellazione 3D per il Design, insegnamento del primo anno della Laurea Magistrale in Design Computazionale al SAAD di Ascoli (Università di Camerino). In questo laboratorio il Visual Programming Language fa da ponte tra la modellazione di prodotti responsivi e le procedure per il Rapid Prototyping. Nell'Atelier di Progetto e Rappresentazione, insegnamento del Corso di Laurea Triennale in Architettura del Politecnico di Torino, la disciplina della composizione si è avvalsa del disegno esplicito per parametrizzare l'evoluzione del processo progettuale, che in più di un progetto ha tenuto conto di fattori ambientali per la generazione dei modelli.

II Politecnico di Torino vede nella transdisciplinarità degli insegnamenti un ambito fertile. Ne è un ulteriore esempio l'insegnamento Modellazione parametrica avanzata dell'involucro edilizio del Corso di Laurea Magistrale in Architettura per il progetto sostenibile, in cui il Visual Programming Language è il luogo di incontro tra Building Information Modeling, Building Physics e Tecnologia dell'architettura.

Sebbene la rappresentazione esplicita sia presente a un livello avanzato dell'indagine architettonica, è quasi completamente assente all'interno di discipline fondanti nella formazione del progettista; in questo saggio si è cercato di sottolineare come la geometria descrittiva possa diventare vera e propria palestra algoritmica per l'addestramento dell'allievo alle problematiche contemporanee presenti nel progetto d'architettura.

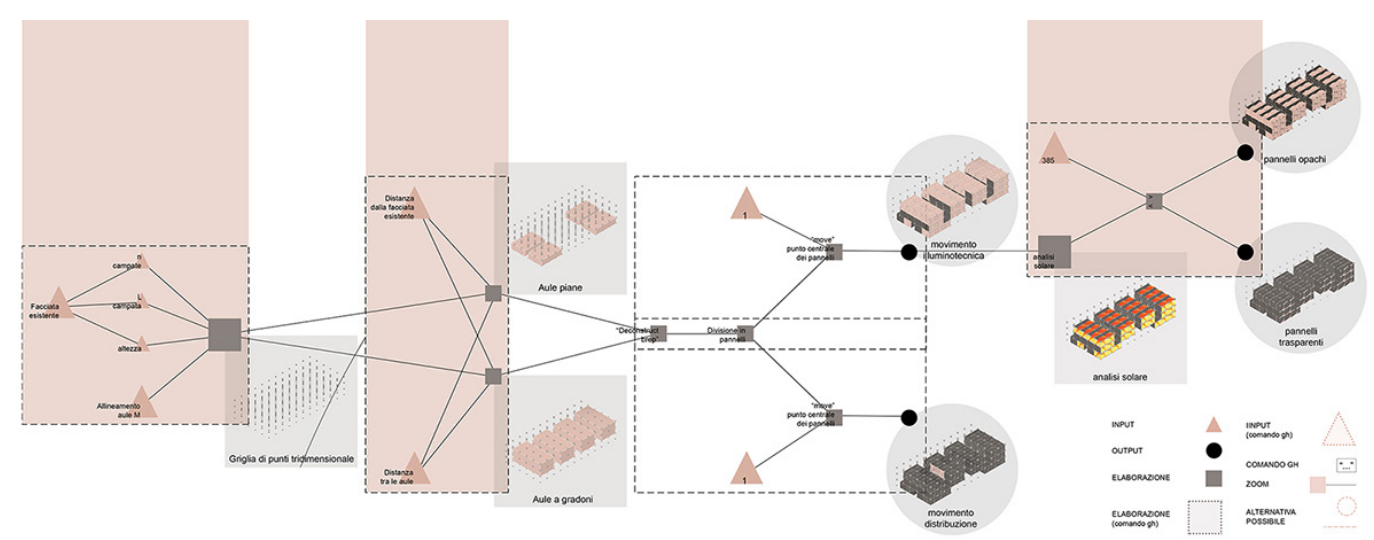




\section{Conclusioni aperte: la scintilla che alimenta il fuoco dell'innovazione}

Ben lontani dal raffrontare le sperimentazioni descritte con le gesta del titano greco, le attività proposte si connotano per una forte accezione sperimentale. Permane una ferma convinzione che sia indispensabile operare una scelta razionale di alcune buone qualità (o buone pratiche, come più comunemente si usa dire ai nostri giorni). I luoghi in cui sperimentare è concesso sono spesso territori di frontiera, non ancora strutturati nei piani di studio in una forma consolidata e disponibile a tutti. Ciò non va visto come un limite, al contrario, fornisce quel margine di libertà necessario per porre in essere processi euristici atti a prevedere risultati che in un secondo tempo vengono controllati e convalidati per via rigorosa. È questo il caso di alcuni workshop introduttivi dedicati ai nuovi immatricolati delle lauree magistrali di Architettura del Politecnico di Torino in cui negli anni sono state sperimentate varie tematiche [I] con aggregazioni disciplinari differenti, le cui esplorazioni sono riproposte in maniera più strutturata nei corsi opzionali e negli atelier [2]. L'Università, nelle sue diverse forme e missioni, non può rinunciare ad alimentare, giorno dopo giorno, la scintilla del progresso e dell'innovazione, con l'obiettivo di rendere i nostri allievi sempre più capaci e competitivi per il successivo ingresso nel mondo del lavoro. E a noi, piccoli e modesti innovatori, resta solo l'augurio di aver miglior sorte del titano Prometeo.

Fig. 10. Immagini che catturano momenti di sperimentazione all'interno di corsi e workshop, eventi in cui la programmazion visuale ha connesso le diverse rapp
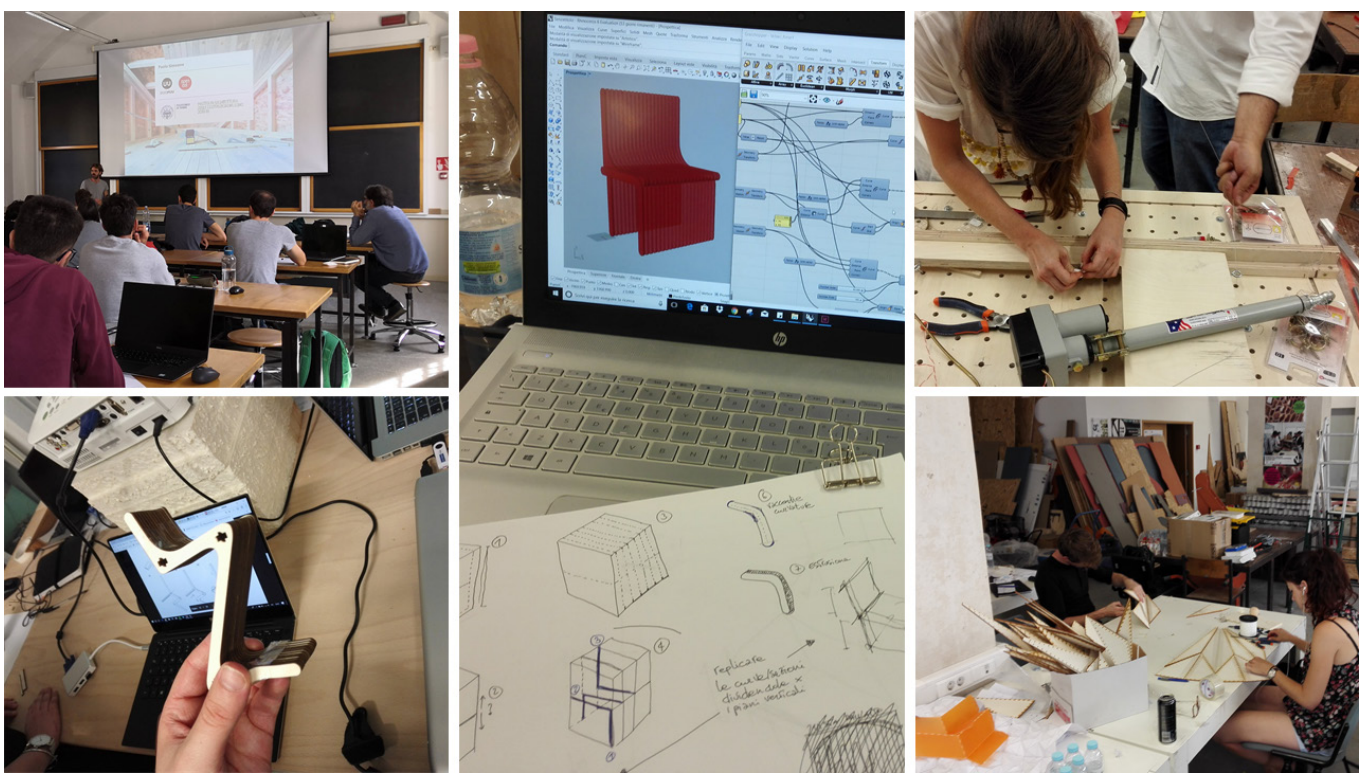

Note

[I] Dalla nuvola di punti all'HBIM (a.a. 2016-2017); Modellazione algoritmica e progetto della forma architettonica e dello spazio urbano (a.a.20 I7-20 I8); Responsive skin (a.a. 20 I8-2019); Parametric Wood Design and Digital Fabrication (a.a. 2019 2020).

[2] Modellazione Digitale dell'involucro edilizio, corso elettivo per il CdL in Architettura per il Progetto Sostenibile (a.a. 20 I92020); atelier Progetto e Rappresentazione, per il CdL in Architettura (a.a. 2019-2020); Parametric Modeling and Design Studio, per il CdL in Architecture (a.a. 2020-202I). 


\section{Riferimenti bibliografici}

Baglioni Leonardo (20/2). Nuove applicazioni della geometria descrittiva: le PQ mesh nell'architettura contemporanea. In DisegnareCon, vol. 5, n. 9, pp. 269-278

Bartoli Gianni, Biagini Carlo, Pellis Davide (2016). Free Form Architecture Engineering: An Applied Methodology for Double Curved Surfaces. In Amoruso Giuseppe. Handbook of Research on Visual Computing and Emerging Geometrical Design Tools. Hershey: IGI Global, pp. 77I-789.

Calvano Michele (2019). Disegno digitale esplicito. Rappresentazioni responsive dell'architettura e della città. Roma: Aracne.

Casale Andrea (20।0). Geometria creativa: intuizione e ragione nel disegno dell'oggetto. Roma: Kappa.

Converso Stefano (2010). Il progetto digitale per la costruzione. Cronache di un mutamento professionale. Santarcangelo di Romagna: Maggioli.

Garzino Giorgio (20 I I). Disegno (E) In Formazione. Disegno Politecnico. Santarcangelo di Romagna: Maggioli.

Giordano Roberto, Lo Turco Massimiliano, Bausola Pagliero Yoseph (2019). Ibridazione tra BIM e VPL: sviluppo di un software per l'Embodied Energy degli edifici. In Lauria Massimo. La Produzione del Progetto. Milano: Maggioli, pp. 327-333.

Mitchell Melanie (1996). An introduction to genetic algorithms. Cambridge:The MIT Press.

Payne Andrew, Issa Rajaa (2009). Grasshopper Primer for versione 0.6.007. <https://static I.squarespace.com static/ 5 I c6f 9f3e 4b0e47ad I bbc7 I c/t/52 I cf940e4b02 I 57 Ifc7d3a5/ / 3776305286 I 5/Grasshopper+Primer_Second+Edition_090323.pdf>.

Saggio Antonio (2007). Introduzione alla rivoluzione informatica in architettura. Roma: Carocci.

Stiny George (1976). Algorithmic Aesthetics. Los Angeles:University of California Press, vol. 9 (2).

Terzidis Kostas (2006). Algorithmic architecture. Amsterdam: Elsevier.

Valenti Graziano Mario, Romor Jessica (2012). Geometria responsiva. In DisegnareCon n. 9, giugno 20 I2, pp. 309-3I6.

Autori

Michele Calvano, Politecnico di Torino, michele.calvano@polito.it

Massimiliano Lo Turco, Politecnico di Torino, massimiliano.loturco@polito.it

Elisabetta Caterina Giovannini, Politecnico di Torino, elisabettiani@polito.it

Andrea Tomolini, Politecnico di Torino, andrea.tomalini@polito.it

Per citare questo capitolo: Calvano Michele, Lo Turco Massimiliano, Giovannini Elisabetta Caterina, Tomalini Andrea (2020). II disegno narrato Esplicitare algoritmi per insegnare la modellazione digitale/The Narrated Drawing. Explicating Algorithms for Teaching Digital Modelling. In Arena A., Arena M., Brandolino R.G., Colistra D., Ginex G., Mediati D., Nucifora S., Raffa P. (a cura di). Connettere. Un disegno per annodare e tessere. Att del $42^{\circ}$ Convegno Internazionale dei Docenti delle Discipline della Rappresentazione/Connecting. Drawing for weaving relationships. Proceedings of the 42 th International Conference of Representation Disciplines Teachers. Milano: FrancoAngeli, pp. 196-215. 


\title{
The Narrated Drawing. Explicating Algorithms for Teaching Digital Modelling
}

\author{
Michele Calvano \\ Massimiliano Lo Turco \\ Elisabetta Caterina Giovannini \\ Andrea Tomalini
}

Abstract

The tools for architectural design have rapidly evolved in recent years, integrating manual design with the use of the computer: through increasingly advanced tools the latest digital platforms, if wisely used, allow a deep and transversal control of the design and construction process, favoring the management of levels of complexity that the technical design does not allow to pursue. Without renouncing the expressive and ideative capacity of manual design, the new tools work efficiently on the relationships between logic and form, geometry, and attributes.

The paradigm of design has changed, a change already underway in professional practice, which must be integrated within the academy; only in this way will digital procedures be fully dominated by future designers to obtain projects with an 'ethical' form.

The present contribution aims at critically reasoning about these instances, between theory and technique, accompanying the narration with some interesting and original didactic experiences that explore the integration between different knowledge, investigating possible connections between a rigorous geometric/logical/formal approach typical of visual programming systems (VPL - Visual Programming Language) using explicit representation.

Keywords

representation sciences, didactics, knowledge integration, descriptive geometry, explicit drawing.

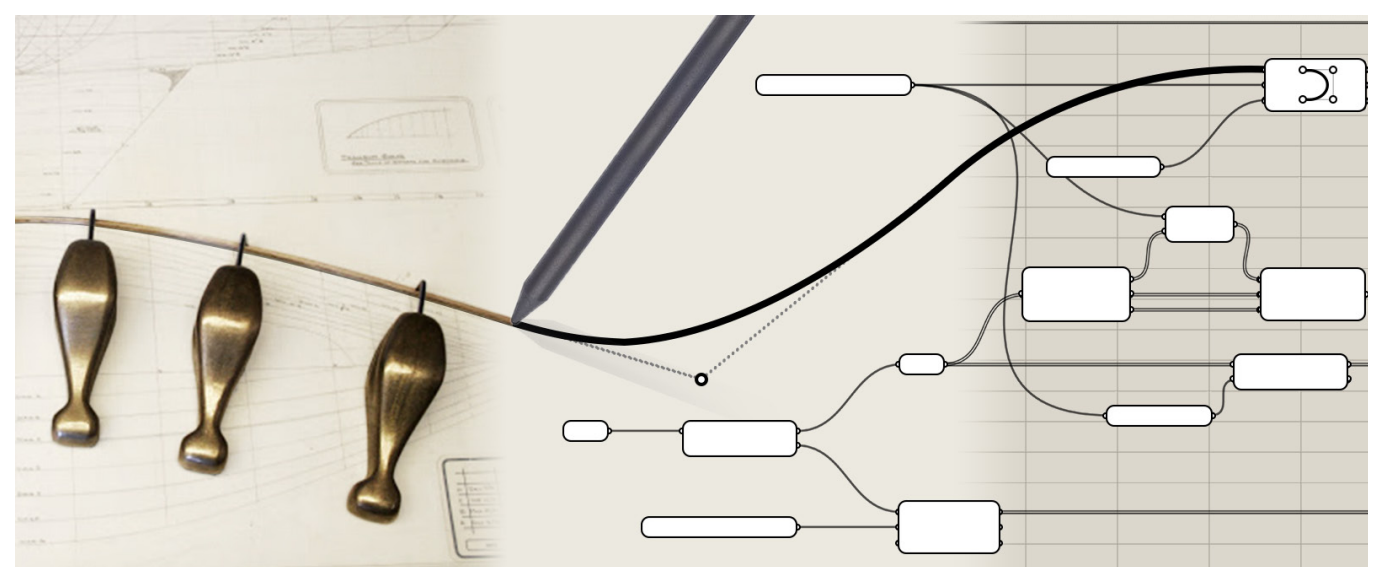




\section{From digital drawing to Explicit Digital Drawing}

For several years now, the representation sector has been using digital tools to draw, investigating a possible link between what are the classic methods of drawing and what are the digital methods. We recall that when we talk about classical methods, we mean orthogonal projections, axonometry and perspective; when we talk about digital methods, we mean mathematical representation (NURBS) and numerical representation (mesh). Digital methods have been widely debated over time by the ICAR/ I 7 sector [Baglioni 20 I2, Bartoli et al. 20 16], producing an extensive literature enriched with experiments that illustrate the limits and potentials of digital methods.

The discussion of the role of classical methods of representation in the age of digital drawing wherein the software adopted supports different areas of architectural design is still ongoing. On the one hand, we have Building Information Modelling software in which the pre-figurative potential of the built project exceeds the speculative possibilities on the shape allowed by the CAD software. The first one, definitely oriented towards project management, can give technical representations that range from the architectural scale to the executive scale of the work; while the second one can complete the first part of the design process that concerns the management of the shape in the conceptual field (figs. I, 2).

Considering the complementary peculiarities between the two tools, it would be interesting to create a dialogue between the two environments; the creation of a single path

Fig. I. Overview and section of the final project prepared with the help of BIM software. Original scale 1:200 (students: E. Melano, A Pizzo, L. Stojan)

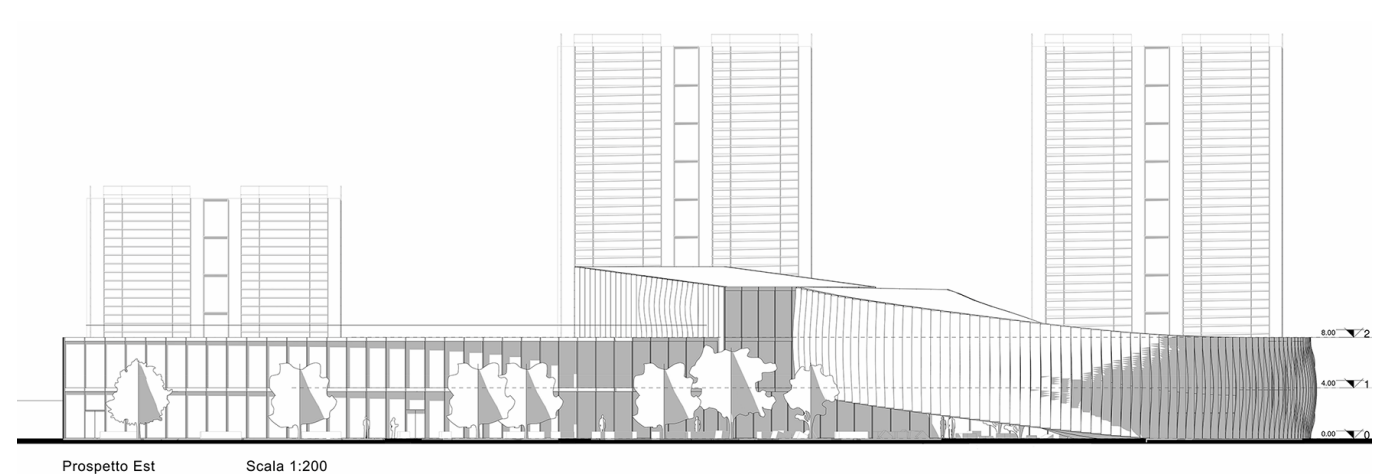

Prospetto Est Scala 1:200

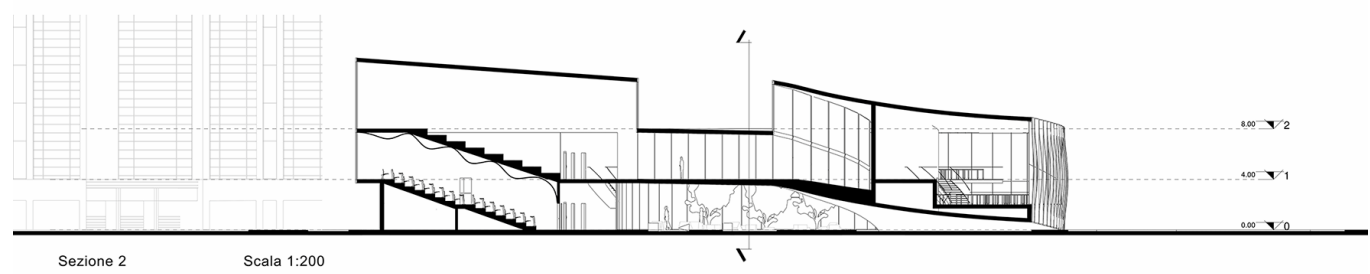

needs strategies to give continuity to the natural consequentiality of the models. We are referring to different images of the design idea that grows during the ideative path, allowing for passage of scale. There's a need to build bridges, connect methods and make models interoperable.

Recently, any drawing software is equipping with graphic interfaces for visual programming with which shapes can be manipulated which the same software makes available. Moving on to Visual Programming Language, with the advent of these applications integrated into the software, various levels of freedom are given to the designer. The interfaces of the programmes collect in a thematic way the components of construction and the modification of the shapes, cataloguing them in special drop-down lists. The User Interface (UI) is certainly a source of support for the immediate use of drawing programmes, making familiar tools to generate models; however, the same $\mathrm{UI}$ is a veil that hides, through the use of macros, the 
Fig. 2. Schematization of the conceptual architectural form in a CAD
environment by building environment by building a continuous model (students: E. Melano, A Pizzo, L. Stojan).

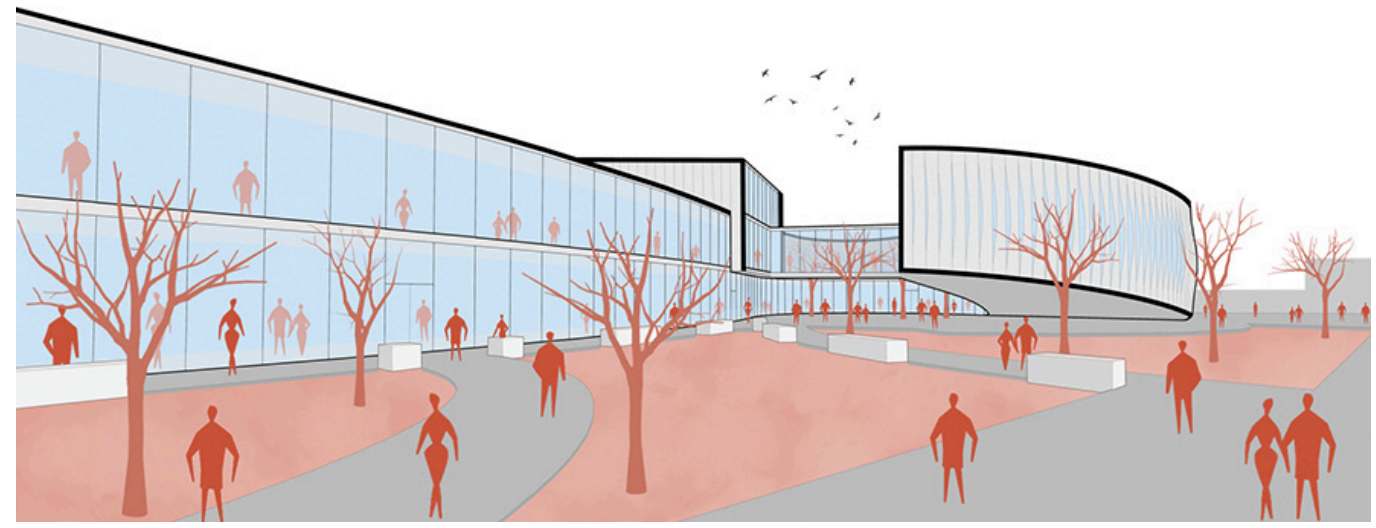

intrinsic potential of the tool. This is one of the reasons why with the advent of digital advancement in the field of drawing, the conception of form and the understanding of space have not been transformed to this day.

The interface makes the software big drawing tables in which the bars that collect the commands are drawing boxes, containing a limited number of tools, similar to those possessed by the now ancient and obsolete technographers. The different commands for the construction of shapes are small pre-constituted paths that, through the introduction of parameters, return simple objects; the shapes are prefigured by a set of these objects and their interconnection. Notably, the compositional paradigm has not particularly changed over time, at least not in some aspects related to faster communication of the compositional steps and the production of technical drawings (fig. 3).

While in the original approach to the model, the construction was based on the composition of pre-constituted macros, the graphic-computational approach allows us to focus on the digital nature of the entities that are generated in a digital environment. The word model becomes key in this way of reasoning; a computer model of a building is in power not only a three-dimensional construction that allows infinite points of view, but also a scientific model: mathematical, financial, physical, statistical model. The data are interrelated and as one changes, the others also vary [Saggio 2007].

The computational aspects require the knowledge of programming languages to directly manipulate the libraries that encode the graphic entities. This knowledge related to the

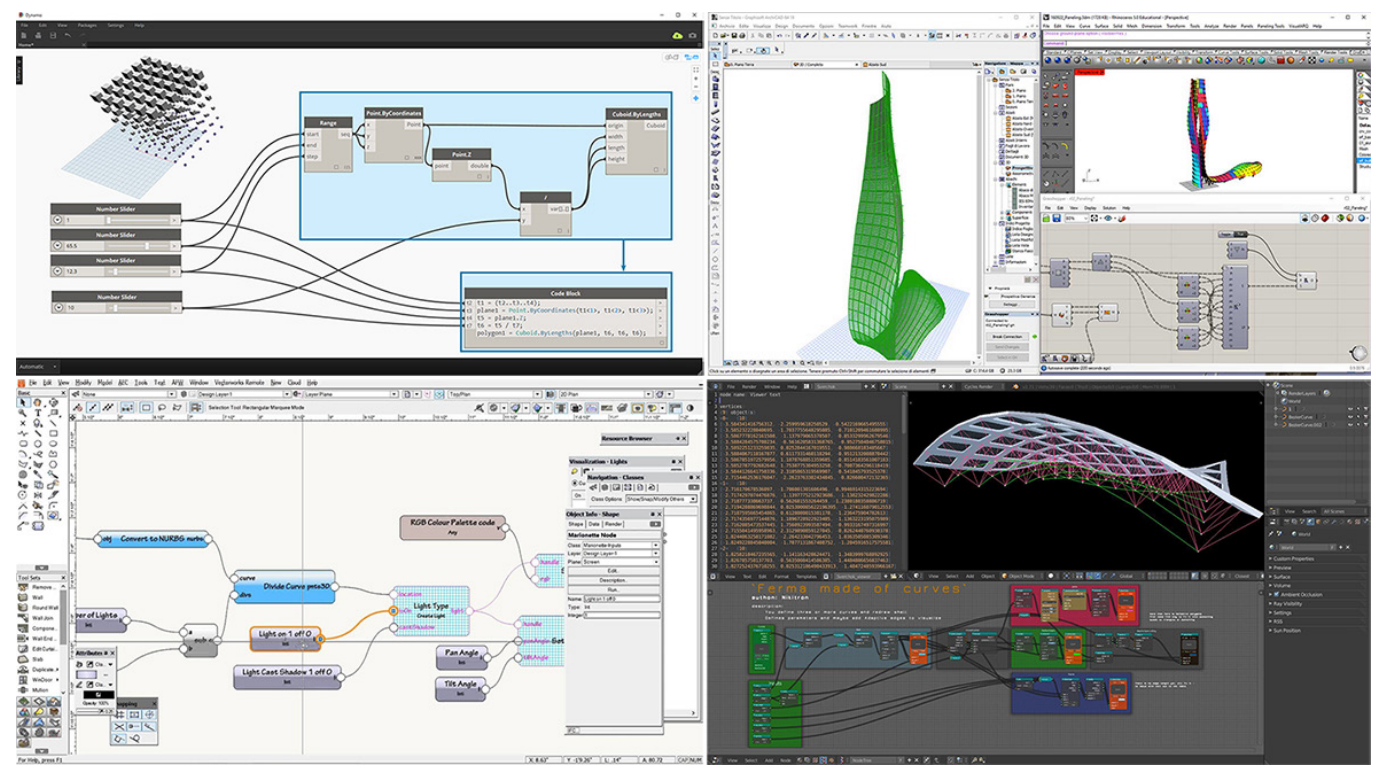

Fig. 3. Ul of some of the most used VPL applications. Dynamo and Marionettes (on the left); Grasshopper and sverchok (on the righ). primer.dynamobim.org/, orum.vectorworks.n cc.ua/>. 
composition of minimum instructions becomes the basis for an evolved design creativity: handling the information level of geometric entities introduces new ingredients in the design with which evolved shapes can be generated. Over time, pioneer designers have introduced rules, different from those imposed by the ruler and the compass, hybridising information from other sectors (Antoni Gaudi, Otto Frei, Felix Candela, Pier Luigi Nervi): mechanical physics, mathematics and statistics. The form is therefore separated from the traditional rules of architectural composition. Explicit Digital Drawing (EDD), through the main tool of Visual Programming Language, makes the process of hybridisation democratic (figs. 4, 5). By Disegno Digitale Esplicito (EDD), we mean the mode of representation of the models

Fig. 4. Sergio Musumeci, model for determinin the shape of the Bridge over the Basento, 1967 (in L'industria italiana de Cemento, n.2, febbraio 1977, p. 77-98).
Fig. 5. Frame of the video The Institute for Lightweight Structure (II) University of Sturcture (IL) University of Otto.

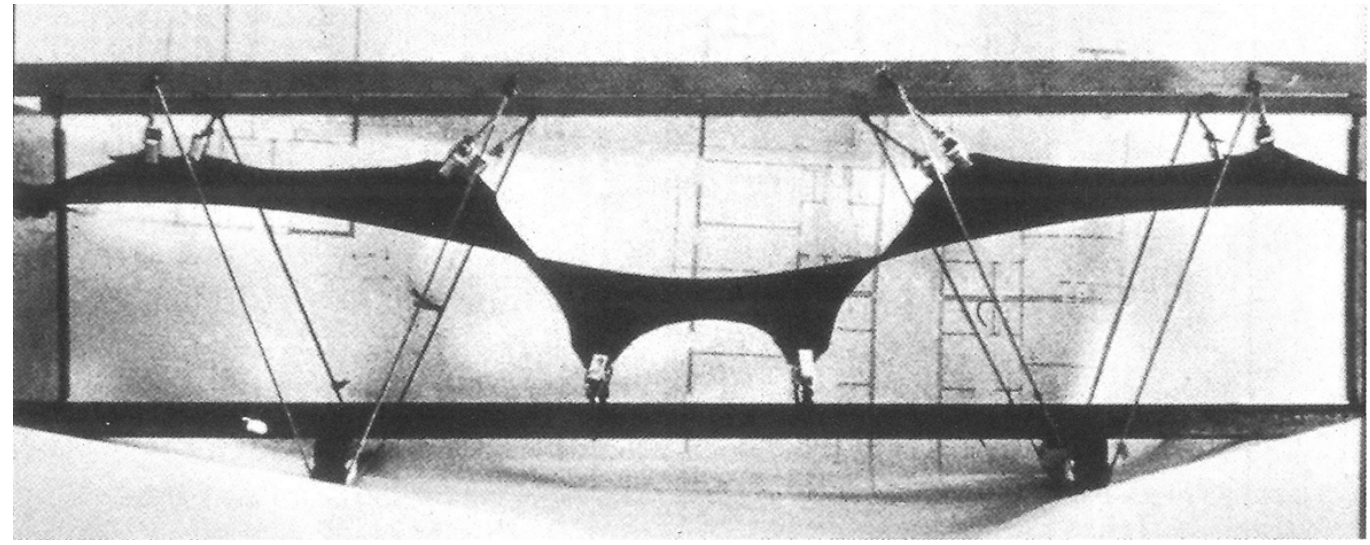

in which the designer's attention is turned towards not only the formal result but also the procedures that generate the image. The balance between the procedure and product highlights new creative modes that manifest themselves both in the visual product and in the procedures that generate the model. The ability to build efficient relationships between data and information linked to a visual model is one of the aims of EDD [Calvano 2019]. These few lines briefly describe the role of the designer, who decides to make use of new computer techniques to represent models: a controlled drawing mode with visual coding tools capable of investigating new areas of representation. These are the areas that drawing disciplines must take into consideration and revise teaching material in drawing courses in architecture schools. This will probably raise a question: where to begin? The answer is to probably begin from the fundamentals.

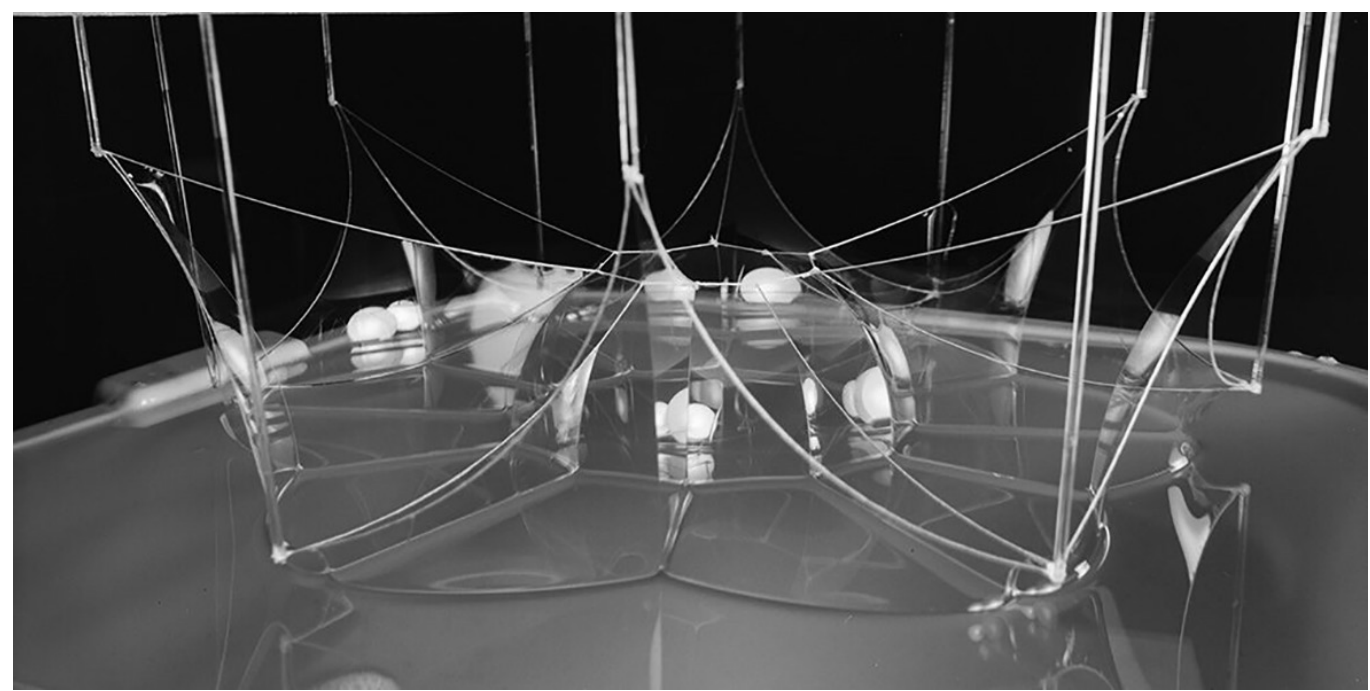




\section{The Fundamental Geometrical Entities - deconstruction}

EDD is an approach that includes new methods of representation but is founded in the classical methods, as they make it possible to prepare the mind for the use of the generative algorithms of shape.

Andrea Casale in the book Geometria Creativa [Casale 20I0], introduces in the first few pages the fundamental geometrical entities, with a drawn representation of a cube in axonometry, disassembled in the faces, lines and points which compose it. "Simple elements, ideas or primitive concepts, necessary for vision and knowledge even before representation.' He then continues his disquisition, describing the line: "the frontal plane of the cube intersects the upper face, defining a portion of the line. The line can only be expressed through its length, it is one-dimensional. The cube is defined by 12 portions of straight lines, its edges". The simple element to understand the fundamental geometric entities is the cube, which in the two-dimensional field of the sheet of paper is represented by an evocative image: a series of signs that remind us of the real object. The method of mathematical representation proposes as a simple entity the boundary representation (bRep), which represents the main entities through its boundaries. Explicit drawing allows recovering the notations previously stated to explain the new minimum entities.

The box in figure 6. is a bRep that is reduced to its minimum entities through a process of object deconstruction. To express this simple procedure, we used Grasshopper, one of the most widely used VPL in research. In the figure, we can see the component deconstruct bRep; in the input (bRep), it asks for the introduction of an open or closed solid and then decompose it in the lists of the minimum entities that constitute it: faces, edges and vertices. By inserting a reading panel for each output listed, we visualise a real list where the entities are indexed with a numerical sequence that starts from 0 and arrives at $n$, where $n$ is determined by the number of specific elements that build the shape. For a cube, we had 6 faces, 12 edges and 8 vertices. We noticed how explicit drawing is a way of constructing/deconstructing the shape whose comprehension finds its benefit in the "algorithmic training" of the descriptive geometry.

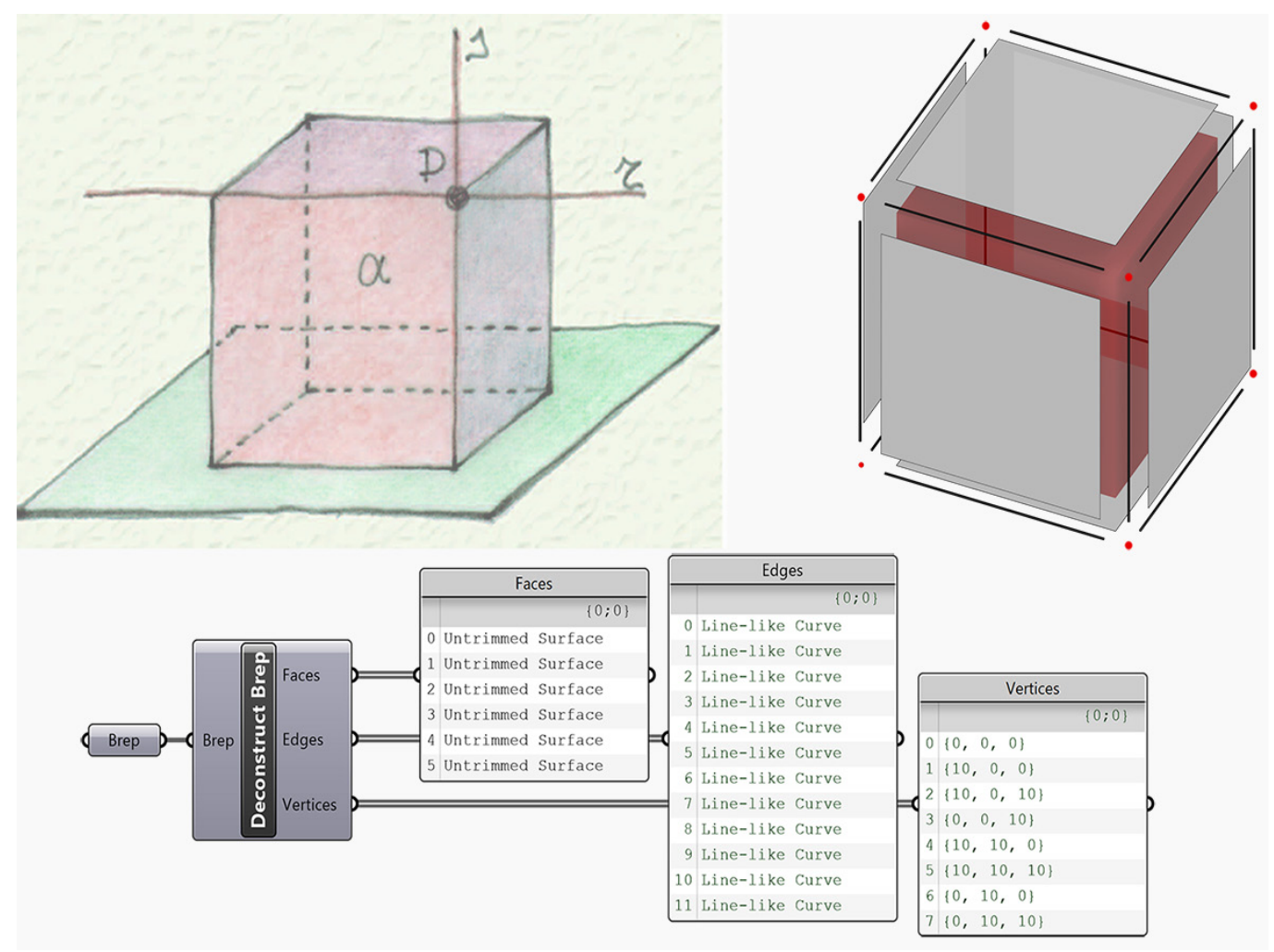




\section{Conditions of belonging - topology}

Descriptive geometry, through the classical methods of representation, is able to describe the scenes present on a plane surface. The transposition of events from the three-dimensional domain to two-dimensional one is possible owing to the clear rules related to the conditions of belonging:

- Two distinct points identify a straight line to which they belong, and which belongs to them. - Two distinct planes identify a line that belongs to them, and to which they belong.

- Two lines intersecting at one point identify a plane to which they belong.

- Two parallel lines identify a plane that belongs to them, and to which they belong.

- Three points that do not belong to the same line identify a plane that belongs to it, and to which it belongs.

- Three planes that do not belong to the same line identify a point that belongs to it, and to which they belong.

- A plane and a line, which do not belong to each other, identify a point that belongs to them, and to which they belong.

- A point and a line that do not belong to each other identify a plane that belongs to them, and to which they belong.

The methods of digital representation thus define the conditions of belonging through the topology, the knowledge of the first ones facilitates the understanding of the second.

We still use the Visual Programming Language to understand how the conditions of belonging, in 3D modelling, assume the role of topology between the parts that constitute the model. Another way to define solids in a digital environment is by the polysurface. In software, this is a collection of entities (points, lines and surfaces) linked together by belonging relationships that act like a glue that gives integrity to the represented polyhedron. What we have here defined as glue is the topology defined by a new list of relations which, together with the list of the minimum entities making up the solid, define its identity within the digital scene.

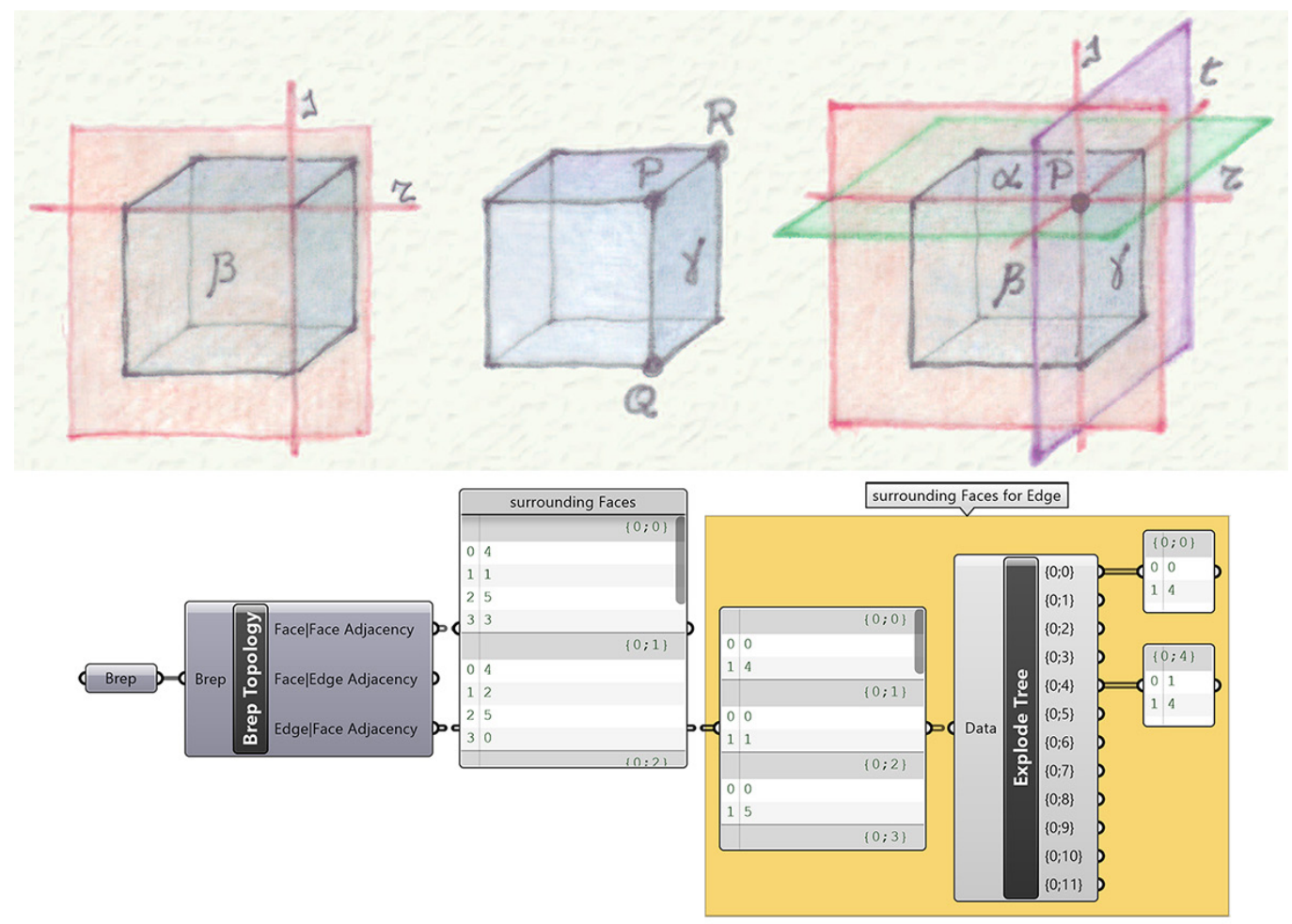


To better understand the concept, we introduce the Brep Topology component (fig. 7) which, upon acquiring the polysurface, lists corresponding adjacent faces for each face (Face - Face Adjacency) and the adjacent edges (Face - Edge Adjacency); and again, for each edge, it extracts a list of faces that converge there (Edge - Face Adjacency).

Now, let's use a panel and connect it to the first output of the component under examination to understand how the topology is indicated numerically. We see that the list of data is split up, creating groups identified by numerical indices in curly brackets (fig. 7). In this specific case, the first number inside the curly brackets is always 0 and separated by a semicolon there is an additional number that identifies the reference face. The elements belonging to each group represent the indices of the faces adjacent to the one defined by the group index.

The explicit representations described above show how the visual algorithms produced led to a new degree of complexity. Explicating a code over time determines the construction of a hierarchical structure, which brings the data and transforms it, creating parallel dependencies and new conditions of belonging which are no longer visually appreciable, but require a capacity for abstraction no longer linked to the disciplinary scope of the drawing (fig. 8). This is the point wherein representation crosses its boundary to enter the computer world, to draw new inspirations from in order to feed the evolution of the discipline.

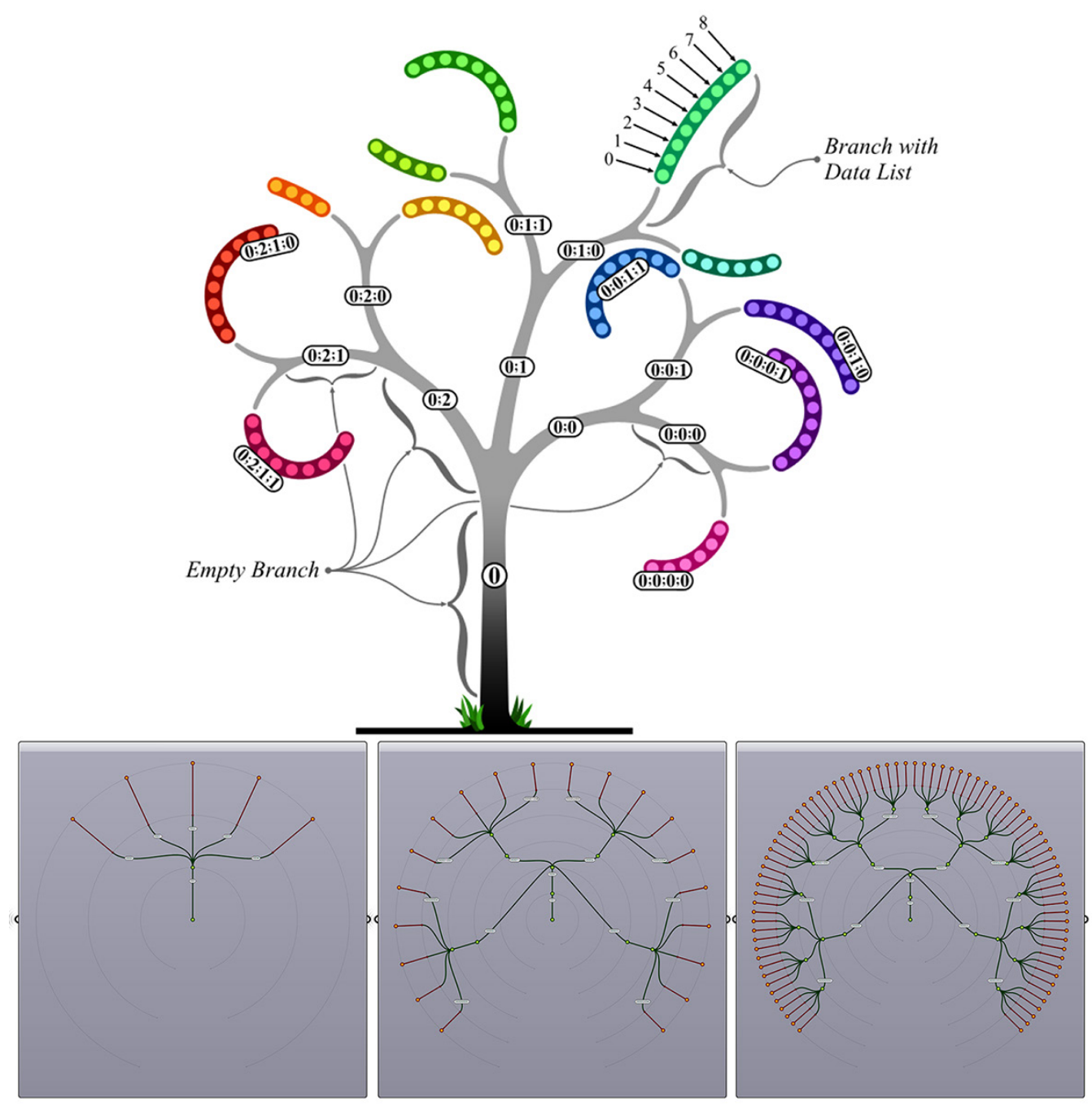




\section{Consistency and prefiguration of DDE}

The explicit drawing, while determining itself through the VPL, leaves a trace of itself, interrupting the final image of the desired shape once it is reached. The trace can be modified into a non-linear way; it can be branched and simplified with a view to computational efficiency. A new language can be written and read, assuming a further narrative logic. This last property gives the explicit digital drawing a didactic value: identical objectives can now be achieved through different approaches, which leave graphic traces of the different experimentations (fig. 9).

The narrative logic of choice is the authentic innovation in the field of computer design because it focuses on the essence of digital innovation. The possibility of processing information flows, even of heterogeneous nature, with which new formal concepts can be developed [Valenti \& Romor 20 I2].

It is an open and interoperable mode which can create a bridge between disciplines. There are more university courses, apart from the ones mentioned here, across Italy that use explicit design for dialogue within ateliers and multidisciplinary courses.

For example, in the course Product Design Studio, within the first year's Master's degree in Product Design, through explicit drawing, students manage a unique, continuously editable workflow, with reverse modelling operations on the point cloud, shape modelling operations and digital fabrication.

Even more relevant is the 3D Modelling Laboratory for Design, a course in the first year of the Master's degree in Computational Design at SAAD in Ascoli (University of Camerino). In this laboratory, the Visual Programming Language acts as a glue between responsive product modelling and rapid prototyping procedures.

In the Atelier of Design and Representation, a course in the three-year course in Architecture at the Politecnico di Torino, the discipline of composition makes use of explicit drawing to parameterise the evolution of the design process, which, in more than one project, has taken into account the environmental factors of models generation.

This university sees the transdisciplinarity of teaching as a fertile field. Another example is the course Advanced Parametric Modelling of the Building Envelope in the Master's degree in Architecture for sustainable design, wherein Visual Programming Language is the meeting place between Building Information Modelling, Building Physics and Architecture Technology. Although the explicit representation is present at an advanced level of architectural investigation, it is contrarily almost completely absent in the founding disciplines of architectural training. In this essay, we have tried to underline how descriptive geometry can become an algorithmic gym and train students in contemporary architectural problems.

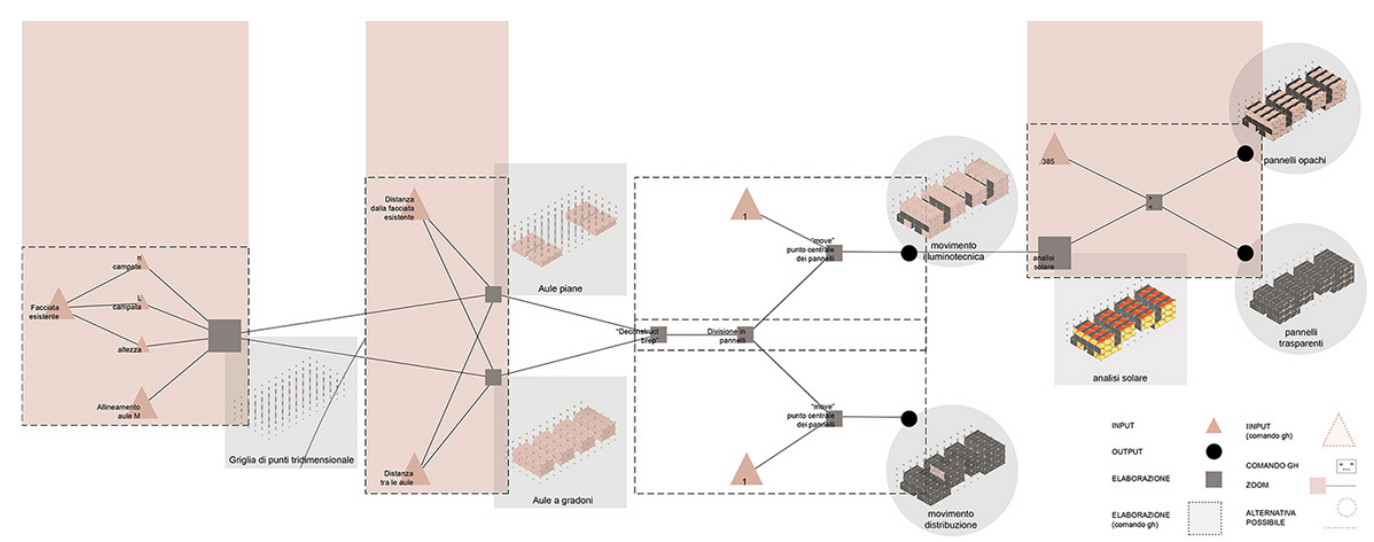




\section{Open conclusions: the spark that fuels the fire of innovation}

Far from comparing the described experiments with the exploits of the Greek titan, the proposed activities are characterized by a strong experimental meaning. There remains a firm conviction that it is essential to make a rational choice of some good qualities (or good practices, as is more commonly said today). The places where experimentation is allowed are often border territories, not yet structured in the curricula in a consolidated form and available to all. This should not be seen as a limitation; on the contrary, it provides the necessary freedom to put in place heuristic processes to predict results that are then rigorously checked and validated. This is the case of some introductory Workshops dedicated to new graduates of the Master Degrees in Architecture at the Politecnico di Torino in which over the years various themes [I] have experimented with different disciplinary aggregations, whose explorations are reproposed in a more structured way in optional courses and workshops [2].The University, in its different forms and missions, cannot renounce to feed, day after day, the spark of progress and innovation, to make our students more and more capable and competitive for the next entry into the world of work. And to us, small and modest innovators, remains only the wish to have better luck than the titan Prometheus.

Fig. 10. Images that catch moments of experimentation within courses and workshops, events in which the visual programming connected the different representations of the project.
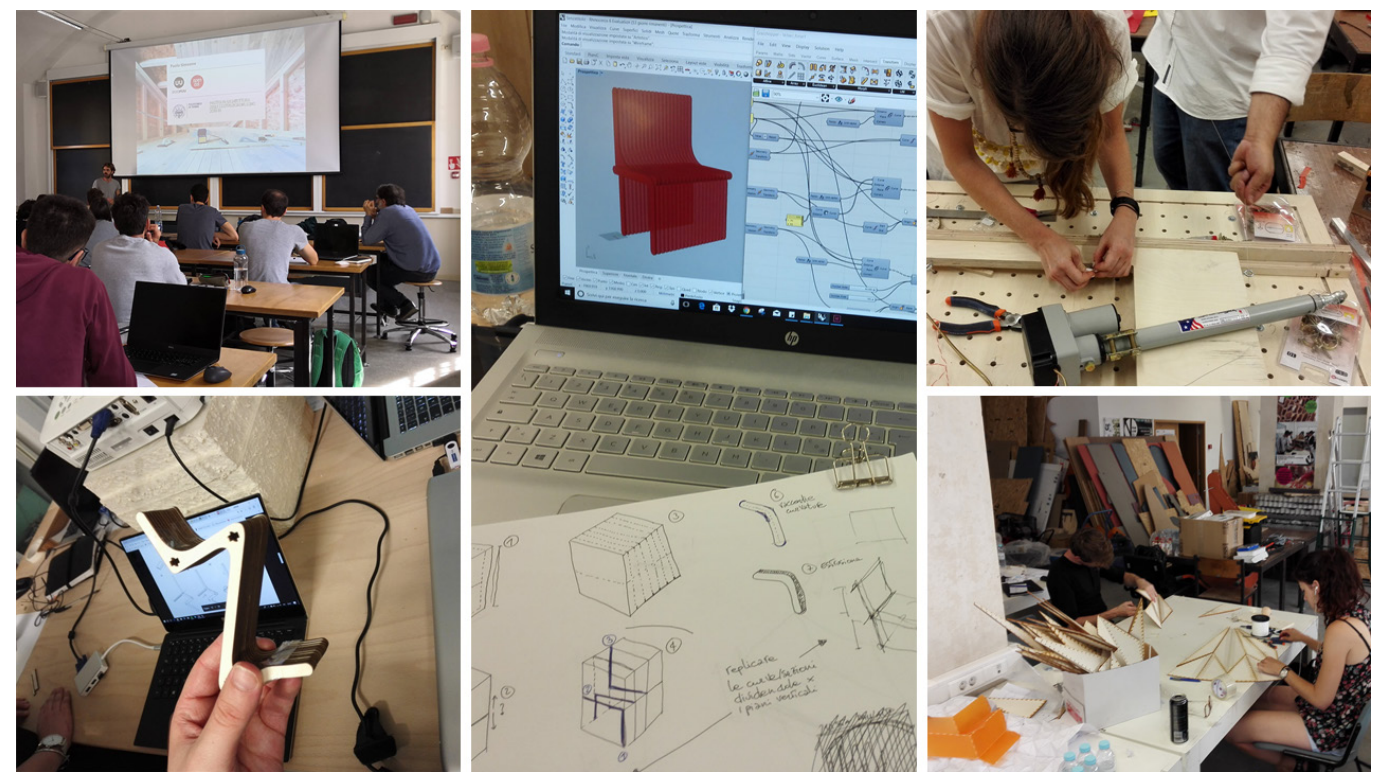

Notes

[I] From the point cloud to HBIM (a.y. 2016-2017); Algorithmic modeling and design of architectural form and urban space (a.y. 2017-2018); Responsive skin (a.y. 20 18-2019); Parametric Wood Design and Digital Fabrication (a.y. 2019-2020).

[2] Digital modeling of the building envelope, elective course for the Degree in Architecture for the Sustainable Project (a.y. 20 19-2020); Atelier Project and Representation, for the Degree in Architecture (a.y. 2019-2020); Parametric Modeling and Design Studio, for the Degree in Architecture (a.y. 2020-2021). 


\section{References}

Baglioni Leonardo (2012). Nuove applicazioni della geometria descrittiva: le PQ mesh nell'architettura contemporanea. In DisegnareCon, vol. 5, n. 9, pp. 269-278.

Bartoli Gianni, Biagini Carlo, Pellis Davide (2016). Free Form Architecture Engineering: An Applied Methodology for Double Curved Surfaces. In Amoruso Giuseppe. Handbook of Research on Visual Computing and Emerging Geometrical Design Tools. Hershey: IGI Global, pp. 77I-789.

Calvano Michele (2019). Disegno digitale esplicito. Rappresentazioni responsive dell'architettura e della città. Roma: Aracne.

Casale Andrea (20।0). Geometria creativa: intuizione e ragione nel disegno dell'oggetto. Roma: Kappa.

Converso Stefano (2010). Il progetto digitale per la costruzione. Cronache di un mutamento professionale. Santarcangelo di Romagna: Maggioli.

Garzino Giorgio (20 I I). Disegno (E) In Formazione. Disegno Politecnico. Santarcangelo di Romagna: Maggioli.

Giordano Roberto, Lo Turco Massimiliano, Bausola Pagliero Yoseph (2019). Ibridazione tra BIM e VPL: sviluppo di un software per l'Embodied Energy degli edifici. In Lauria Massimo. La Produzione del Progetto. Milano: Maggioli, pp. 327-333.

Mitchell Melanie (1996). An introduction to genetic algorithms. Cambridge:The MIT Press.

Payne Andrew, Issa Rajaa (2009). Grasshopper Primer for versione 0.6.007. <https://static I.squarespace.com static/ 5 I c6f $9 f 3 e$ 4b0e47ad I bbc7 I c/t/52 I cf940e4b02 I 57 Ifc7d d3a5/I 3776305286 I 5/Grasshopper+Primer_Second+Edition_090323.pdf>.

Saggio Antonio (2007). Introduzione alla rivoluzione informatica in architettura. Roma: Carocci.

Stiny George (1976). Algorithmic Aesthetics. Los Angeles:University of California Press, vol. 9 (2).

Terzidis Kostas (2006). Algorithmic architecture. Amsterdam: Elsevier.

Valenti Graziano Mario, Romor Jessica (20 I2). Geometria responsiva. In DisegnareCon n. 9, giugno 20 I2, pp. 309 -3 I6.

Authors

Michele Calvano, Politecnico di Torino, michele.calvano@polito.it

Massimiliano Lo Turco, Politecnico di Torino, massimiliano.loturco@polito.it

Elisabetta Caterina Giovannini, Politecnico di Torino, elisabettiani@polito.it

Andrea Tomolini, Politecnico di Torino, andrea.tomalini@polito.it

To cite this chapter: Calvano Michele, Lo Turco Massimiliano, Giovannini Elisabetta Caterina, Tomalini Andrea (2020). II disegno narrato. Esplicitare algoritmi per insegnare la modellazione digitale/The Narrated Drawing. Explicating Algorithms for Teaching Digital Modelling. In Arena A., Arena M., Brandolino R.G., Colistra D., Ginex G., Mediati D., Nucifora S., Raffa P. (a cura di). Connettere. Un disegno per annodare e tessere. Atti del $42^{\circ}$ Convegno Internazionale dei Docenti delle Discipline della Rappresentazione/Connecting. Drawing for weaving relationships. Proceedings of the 42th International Conference of Representation Disciplines Teachers. Milano: FrancoAngeli, pp. 196-215. 